\title{
VELFÆRDSSTATENS NORMATIVE GRUNDLAG ${ }^{1}$
}

\author{
Jørn Henrik Petersen
}

\begin{abstract}
ENGLISH ABSTRACT: The contribution develops the specific character of the Danish welfare state based on a decoupling of the individual's financial and other contributions from his or her rights to benefits. This characteristic is opposed to the more or less equivalent reciprocity marking most other welfare states. The objective is to unfold an ontological ethics as an interpretative frame for understanding the normative basis of the Danish prototype. The tension between the implied mode of being and the individuals' daily doing is analysed. The contribution is concluded by a heuristic reflection on the relation between the mode of being and a general religious frame of reference.
\end{abstract}

DANSK RESUME: Artiklen udvikler den danske velfcerdsstats egenart baseret på en afkobling på det individuelle niveau af det finansielle grundlag og retten til ydelser $i$ modscetning til andre velfcerdsstaters anvendelse af mere eller mindre akvivalent reciprocitet. Formålet er at give et bud på et muligt normativt grundlag bag denne konstruktion. Hypotesen er, at en ontologisk baseret etik modsvarer prototypens egenskaber. Videre udvikles spcendingsforholdet mellem den herafflydende varensordning og den enkeltes daglige gøren og laden. Bidraget afsluttes med en heuristisk refleksion over forholdet mellem velfordsstaten som begreb og en almen religiøs dybdestruktur.

KEY WORDS: Welfare state; reciprocity; ontological ethics; mode of being.

\section{Prolog}

Har velfærdsstaten et etisk grundlag, eller er den et konglomerat af interessernes kyniske samspil og modspil? Det er det spørgsmål, denne artikel kredser om. Den har fokus på den danske velfærdsstat, der som idealtype adskiller sig fra både den Bismarck-inspirerede kontinentaleuropæiske og den Beveridge-motiverede engelske velfærdsstatsmodel. De bygger alle på en såkaldt social kontrakt, som sikrer omfordeling af den enkeltes indkomst over livsløbet; men 'kontraktens' udformning er forskellig, fordi de to har reciprociteten - koblingen mellem den enkeltes bidrag og hans eller hendes ydelse - som kerne. Derimod hviler den danske prototype på finansiering over generel beskatning og individuelle ydelser, hvis størrelse er uafhængig af den enkeltes skattebetaling. Da 'ydelse og modydelse' ofte ses som samfundets kerne-

\footnotetext{
${ }^{1}$ En stor tak til professor, dr.theol. Ole Jensen for gode kommentarer til en tidligere udgave af dette bidrag. Også en tak til forskningslektor Kees van Kooten Niekerk, der venligt har stillet et endnu upubliceret manuskript "K.E. Løgstrups politiske tænkning” til min rådighed.
} 
relation, er spørgsmålet, hvad der er på færde i den danske velfærdsstat. Hypotesen er, at den danske samfundskonstruktion er funderet $i$ et ontologisk perspektiv, der bygger på den indbyrdes menneskelige afhængighed som et værensvilkår - en tanke, man delvis finder hos den engelske sociolog Alvin Gouldner (1920-1980), og som er fuldt udfoldet hos den danske religionsetiker Knud E. Løgstrup (1905-1981). ${ }^{2}$ Mens den rene reciprocitet indebærer symmetrisk ækvivalens i udvekslingerne mennesker imellem, forudsætter den ontologisk begrundede velfærdsstat en anden og anderledes værensorden, der placerer den i et spændingsfelt mellem dens etiske grundforudsætninger og den menneskelige praksis. Ræsonnementerne afsluttes med en tentativ overvejelse af, om den velfærdsstatslige værensorden - samfundets nomos - kan fastholdes uden en religiøs referenceramme.

\section{Intention og interesse}

Velfærdsstaten er en politisk frembringelse, fordi den er et resultat af beslutningstagernes 'læggen lag på lag' i politiske kompromisser. Forskellige aktører har med forskellige motiver over tiden føjet større eller mindre dele til. Velfærdsstaten nyder i dag af meget forskellige årsager opbakning fra meget forskellige lejre, der lægger vægt på forskellige aspekter. Den har også sine kritikere, som er kritiske hver på deres måde. Velfærdsstaten er m.a.o. ikke en homogen og entydig størrelse men et rodsammen af programmer, der ikke nødvendigvis er afstemt med hinanden. Det kan derfor virke som halsløs gerning at ville diskutere etikken bag velfærdsstaten.

Ofte vil man, når det drejer sig om en social institution, både med definition og etisk retfærdiggørelse for øje, kigge på grundlæggernes intentioner; men når det drejer sig om velfærdsstaten, er der ingen entydig ophavsmand og ikke et veldefineret sæt af intentioner (Goodin 1988). Hvordan skulle man kunne afdække en samlet intention bag en institution, der er udviklet af skiftende lovgivende forsamlinger med forskellige medlemmer i varierende koalitioner ved tilføjelse af nye og ændringer i bestående programmer i mere end hundrede år?

Det er betragtninger som disse, der lå bag professor Jørgen Dichs (1901-1975) vurderinger af samspillet mellem interesser og idéer. Fx understregede han (Dich 1958) i 1958, at de forskellige tilskud, som større eller mindre grupper i befolkningen oppebar, ikke var udsprunget af en generel teori om en samfundsmæssig bedre ordning. De var en følge af politiske krav, der sigtede på fordele for bestemte befolkningsgrupper, og som satte sig igennem, når to eller flere grupper - med politisk eller økonomisk gevinst for øje - fandt sammen i et kompromis.

I 1965 tog han atter - i en analyse af skatte- og tilskudspolitikken gennem perioden fra 1939 til 1965 - temaet op (Dich 1965). Førkrigstidens hævdvundne lighedsprincip var, hævdede han, forladt, og middelstanden havde erobret socialpolitikken gennem tilskud $\mathrm{i}$ en form, der lod virkningerne være skjulte for andre end de indviede.

\footnotetext{
${ }^{2}$ Kees van Kooten Niekerk har henledt min opmærksomhed på Alasdair MacIntyre, 1999. Dens pointer synes beslægtet med synspunkterne i denne artikel, men de er ikke inddraget.
} 
Forklaringen lå i politikernes bestræbelser på at bevare eller erobre regeringsmagten. Udviklingen var ikke resultat af et program eller en ideologi, men fulgte af en hensyntagen til grænsevælgerne. Bekendelsesideologierne tjente alene en symbolsk indrømmelse til de fordringer, partimedlemmerne gjorde gældende.

I den kendte bog Den herskende klasse (Dich 1973) så han 'den tjenende stand' forvalterne af velfærdssamfundets serviceydelser - som en herskende klasse, der havde opbygget en ideologi med stærk instinktiv støtte i befolkningen. Den bundede, advokerede han, i humanismens sociale, menneskelige forståelse (socialsektoren), i ønsket om sundhed og angst for døden (sundhedssektoren) og i middelstandens foragt for det legemlige arbejde (uddannelsessektoren). Og den klasse, der skaber et lands ideologi, former også politikerne i sit billede og vinder derved magt.

Med skiftende accentueringer er de tre arbejder helt i tråd med de principielle ræsonnementer, man finder i hans anmeldelse af professor Niels Lindbergs (1904-1971) nu af de fleste glemte disputats om idealer og regler i anvendt økonomi (Lindberg 1951). Dichs hovedpointe (Dich 1952) var, at verden er behersket af stræben efter penge og magt. Det er de faste størrelser, som idealerne tilpasser sig. Idéerne ændrer ikke interesserne, men tenderer snarere at forstærke dem, fordi de tillægger de mere egoistiske interesser et skær af højhed og samfundsgavnlighed. Dette er - ifølge Dich så meget mere muligt, fordi de fleste idéer er ret udflydende og ubestemt formuleret og derfor åbne for det indhold, visse interesser på et givet tidspunkt vil tillægge dem. Idéerne bringes til sejr, når de støtter sig til de sejrende politiske interesser - ikke fordi de besidder en immanent kraft.

\section{Den implicitte sociale kontrakt}

Dichs forståelse kan have en del for sig, hvis man alene ser på de enkelte ordningers tilblivelse og udvikling; men i et mere overordnet perspektiv er det bemærkelsesværdigt, at de har en række fælles træk, som er forskellige fra dem, man finder i andre lande. Der synes idealtypisk at være en egenartet dansk velfærdsmodel konstrueret på en egenartet dansk velfærdsstatslogik. Det kunne måske antyde, at der i dybdestrukturen er forhold, som spejler et sæt af - bevidste eller ubevidste - værdier. Politologen Tim Knudsen $(2000 \mathrm{a}, 10)$ peger da også på, at velfærdsstatens idéer og principper synes at afspejle noget dybere liggende i den kulturelle baggrund, end det der er kommet til udtryk i partipolitiske programmer, og, kunne man tilføje, det, som umiddelbart fremgår af intentioner bag enkeltstående ordninger. Det kalder på en tolkning af historien med større historisk og kulturel dybde.

De, der søger velfærdsstatens etiske fundament, analyserer oftest velfærdsstatens historie og politik, men møder i analysen en flerhed af ikke specielt sammenhængende værdier - et pluralistisk værdisystem. Det er der ikke noget 'galt' i, fordi det netop betyder, at 'det rigtige' er genstand for forhandling. Den 'løsning', som i en given situation vælges, er konsekvens af det i situationen foreliggende mulighedsområde i samspil med de involverede aktørers præferencer. Politiske aktører er ikke nødvendigvis konsistente i deres argumentation over tid, og partier med samme ideologiske disposi- 
tion er ej heller nødvendigvis konsistente over tid eller på tværs af lande. Derfor er det mere givende at skære ind til benet $i$ et forsøg på at bestemme en bestemt velfærdsstats idealtypiske 'løsning', som spejling af et bevidst eller ubevidst paradigmatisk syn.

Den danske velfærdsstat har fra sin spæde begyndelse i 1890'erne grundlæggende været baseret på tanken om en implicit social kontrakt mellem generationerne og mellem medlemmer af den enkelte generation. Man kan finde en rudimentær forståelse af tanken i Danmark allerede forud for 1890'erne (Petersen 1986), selv om det teoretiske grundlag skyldes den tyske socialøkonom W. Schreiber (1904-1975) (Schreiber 1955) og den amerikanske økonom P.A. Samuelson (1958). Begge bygger på, at generationerne 'overlapper' hinanden.

\section{Figur 1. Den implicitte sociale kontrakt mellem generationerne}

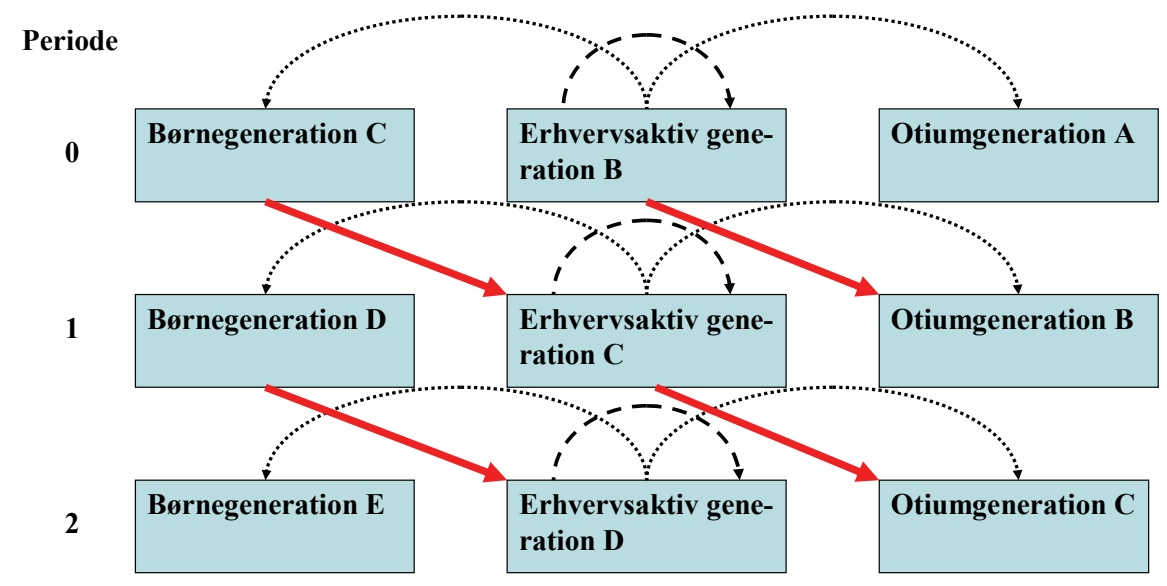

Ser man i figur 1 isoleret på periode 1 , er det den erhvervsaktive generation $\mathrm{C}$, som forsørger den samtidige 'afhængige' børnegeneration D og otiumgeneration B enten gennem skatte- eller bidragsbetaling eller som led i familiernes forbrug. I medierne beskrives generationen $\mathrm{C}$ som 'skaffedyr', men det er i en vis forstand en illusion. I periode 0 blev nemlig generationen $\mathrm{C}$ som børnegeneration forsørget af forældregenerationen $\mathrm{B}$, og $\mathrm{C}$ forventer i periode 2 at blive forsørget af generationen $\mathrm{D}$ - dens egne børn. Billedligt kan man se generation $\mathrm{C}$ forlade periode 0 med en 'gæld' til generation B. Den indfries i periode 1 , hvor C samtidigt oparbejder en fordring på generation $\mathrm{D}$ til indfrielse i periode 2 .

Den sociale kontrakt indebærer også i den enkelte periode en omfordeling mellem forskellige grupper blandt de erhvervsaktive. De, der ikke rammes uheldigt af livets tilskikkelser, yder til dem, som har været mindre heldige. Det portrætterer samfundet 
som en stor forsikringsordning eller som en udvidet familie (Westergaard 1926). Den mere eller mindre fælles risikodækning afspejler den forståelse, at alle borgere potentielt er udsat for risici, og at der derfor er et fælles ansvar for at imødegå konsekvenserne, når den ene eller den anden 'rammes' af en begivenhed, som udspringer af en risiko, der er accepteret som 'social'. Undertiden finder man det normativt ladede synspunkt, at 'vi alle er i samme båd' (Kildal \& Kuhnle 2005a, 22).

Denne del af den sociale kontrakt har principielt samme grundlag som den private forsikring, men adskiller sig, fordi alle tvangsmæssigt er medlem af risikofællesskabet. Med uforudsigelighed og lige risiko er det ud fra et traditionelt utilitaristisk ræsonnement rationelt at etablere en sådan forsikring; men risikoen er ikke nødvendigvis den samme for alle. Kontrakten bygger grundlæggende på bevidstheden om den enkeltes skiftende rolle, men den er sårbar, fordi 'de heldige' eller 'de stærke' i midtergruppen let får en selvopfattelse som 'skaffedyr'. Jo flere, der vedvarende parkeres som 'afhængige' af overførselsindkomster, jo større er risikoen for en tænkning i termer af 'dem' og 'os'. Det kan dreje sig om danske befolkningsgrupper, der er marginaliseret eller udstødt fra arbejdsmarkedet, eller det kan dreje sig om grupper af 'anden etnisk herkomst', som ikke har vundet fodfæste på arbejdsmarkedet og kun har ringe udsigt til at gøre det. Des mere et sådant syn vinder frem, des stærkere vil der lyde røster til fordel for et 'noget for noget'-synspunkt, jf. neden for. Det kan finde udtryk i en stærkere vægtlægning på individualiserede institutioner eller $i$ en kraftigere betoning af 'workfare'. Og det kan på det lange sigt pege mod en polarisering, der for alvor vil udfordre en velfærdsstat af den danske type.

Skal en social kontrakt, når det drejer sig om forholdet mellem generationerne, fungere uden friktioner, må den erhvervsaktive generation i enhver periode betale forsørgelsen for de samtidige generationer af børn/unge og ældre, og den må sikre den biologiske reproduktion, så der i den efterfølgende periode er en tilstrækkelig stor erhvervsaktiv generation, som kan bære kontrakten videre. Indtræeder der, som tilfældet har været i den sidste halvdel af det 20 . århundrede, et mere eller mindre permanent fald i fødselshyppigheden, kan der være risiko for kontraktens sammenbrud, ikke mindst hvis der samtidig er vækst i middellevetiden. Der vil kunne indtræde en så betydelig omfordeling mellem generationerne, at det kan være en trussel mod tilliden til kontraktens indfrielse.

\section{Fælles træk og forskelle}

I udformningen af den sociale kontrakt på det individuelle plan kan kontrakten antage flere former. Figur 2 illustrerer to idealtyper, der repræsenter grundforskellen på det tyske - ikke mindst efter den af Schreiber (1955) inspirerede pensionsreform fra 1957 og det danske system.

Det fælles træk er, at de begge på makroniveauet bygger på reciprocitet $\mathrm{i}$ forholdet mellem generationerne. Forskellen er, at det enkelte individ i den tyske model mere direkte overfører fra sig selv til sig selv. Den enkeltes bidragsbetaling som erhvervsaktiv og vedkommendes relation til arbejdsmarkedet bestemmer både, hvad han eller 
hun får i den efterfølgende periode, og hvad hun eller han er berettiget til som led i den interne omfordeling mellem 'heldige' og 'uheldige' i den enkelte erhvervsaktive generation. Der er en kobling mellem 'ydelse' og 'nydelse', som den kendes fra markedets udvekslinger.

\section{Figur 2. Forskellen mellem den tyske og den danske velfardsmodel. Kobling og afkobling.}

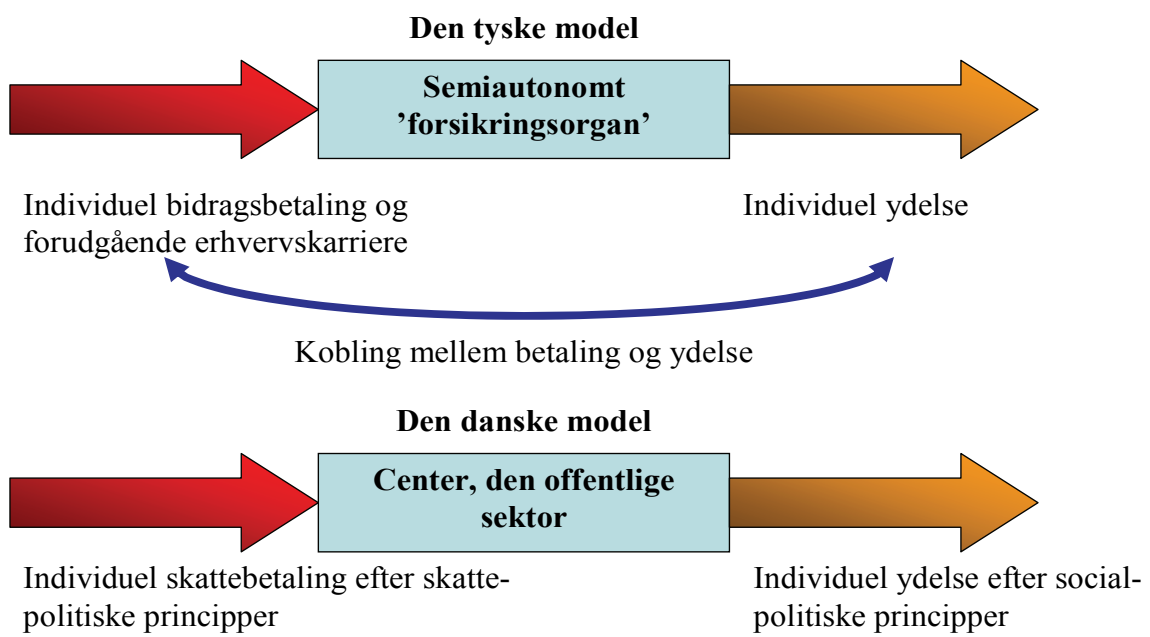

Afkobling mellem betaling og ydelse

Disse egenskaber, understreger den tyske sociolog Claus Offe (1990), garanterer befolkningens risikovillighed (tillid til fremtiden) og systemsolidaritet (tillid til 'de andre') i en grad, så man næppe kan forestille sig rationelt begrundede forbehold over for sikringssystemet. Det er såvel kognitivt som moralsk fordringsløst og sikrer den enkeltes subjektive bevidsthed om at få, hvad hun eller han er berettiget til, mens ingen får noget, vedkommende ikke har fortjent. Garanten for tilliden til systemets fremtid og til 'de andre' ligger i dets markedslignende struktur, der ækvivalent kobler betaling og ydelse. På samme måde understreger Koslowski (1997, 371) borgernes ønsker om anerkendelse som ansvarlige individer. De ønsker derfor ikke pensioner som tildelt velgerning, men som en ret der følger af bidragsbetalingen. De køber en følelse af at have betalt for en fordring.

Denne argumentation kan knyttes direkte til Margaret Levi's (1991, 135) [refereret efter Rothstein (1996, 111-12)] argumentation for 'kontingent enighed': Politikken skal være generelt fair, dvs. ikke-diskriminerende. Den skal bæres af proceduremæssig retfærd, dvs. fairness i dens gennemførelse. Og den skal bygge på, at andres bidrag er fair, dvs. at de hverken bidrager for lidt eller for meget. Det pudsige er, at Rothstein 
tager dette som argument for den såkaldt universelle velfærdsstat, mens det i den tyske kontekst er argument for en udpræget 'noget for noget' konstruktion. Og de to konstruktioner må vel siges at være forskellige?

Koblingen er ikke til stede i den danske model, fordi den pålægger den enkelte at betale skat efter skattepolitiske synspunkter som fx, at 'de bredeste skuldre skal bære de største byrder', mens ydelserne fordeles efter socialpolitiske betragtninger, der lægger vægt på en hensyntagen til svagere grupper og på generel indkomstomfordeling. Der er derfor ikke tale om den ækvivalens mellem 'at give' og at 'modtage', som kendes fra markedet. Ydelserne og deres finansiering er afkoblet. Nogle får noget, der modsvarer, hvad de har givet afkald på. Andre får mere eller mindre. Nogle får 'noget for ingenting'. Det kalder på en forklaring.

I deres analyse af universalismen som normativt grundlag bag den nordiske velfærdsstat, noterer Kildal \& Kuhnle (2005a, 25), at de ikke har fundet en klart formuleret politisk vision bag de politiske initiativer bag udviklingen af den universelle velfærdsstat, men at universalismen på den anden side næppe kan opfattes som resultat af et interessebetonet kompromis eller en forhandlingsproces. De tolker derfor udviklingen inden for rammerne af en lang, dynamisk proces på vejen mod en 'overlappende enighed' i Rawls' (1993, 15 samt lecture IV) forstand. I en gradvis proces indlejres en gang vedtagne institutioner i den bagved liggende kultur, og der udvikles en 'vi-følelse' af solidaritet, fælles standarder, kultur, identitet, visioner, symboler, historie og moralsk tydningsunivers.

Det er en beslægtet tanke, der ligger bag dette bidrag. Ikke mindst i perioden forud for vedtagelsen af aldersrenteloven i 1922 og i nogen grad i årene frem mod folkeforsikringsloven af 1933 stod mening mod mening, når det drejede sig om valget mellem kobling og afkobling mellem ydelser og finansiering, men gradvis udkrystalliserede der sig en tolererende accept af afkoblingen som idé (Petersen 2006). Det er måske også denne tanken om overlappende enighed, der finder udtryk hos Stråth (2005, 47), når han ser det sociale demokrati som en samtidig kontinuering og transformation af lutherdom, sognepolitisk kultur, socialliberalisme, ja, endog reformkonservatisme og som kerne i den skandinaviske håndtering af de iboende spændinger mellem frihed og lighed.

\section{Reciprocitetens nærvær eller fravær}

I sin nu klassiske bog Gaven (Mauss 2000) viste den franske sociolog og antropolog Marcel Mauss (1872-1950), at gavegivning er kerne i den menneskelige vekselvirkning. Det havde allerede den tyske sociolog Georg Simmel (1872-1950) udmøntet (Simmel, 1907 og 1908), da han understregede 'given' som en af de stærkeste sociologiske funktioner. Uden at der i et samfund løbende gives og modtages - også uden for det økonomiske bytte - ville intet samfund være muligt (Simmel 1908, 592). Inden for, hvad Mauss kalder et 'system af totale ydelser' $(2000,18)$, har udvekslingen tre elementer $(2000,26)$ : forpligtelsen til at give, til at tage imod og til at gengælde. Hans analyse af de arkaiske samfund knyttes til den begyndende udvikling af velfærdsstaterne 
(2000, 91). Den arbejdende har givet sit liv og sit arbejde både til fællesskabet og til arbejdsgiveren, som han eller hun derfor har en fordring på. De bidrag til samfundet, den enkelte har ydet gennem sit arbejde eller ved andre former for indsats, er for Mauss den 'given', der gør det legitimt at tage imod, og som gør det naturligt at gengælde, hvis processen udspiller sig i tid: Velfærdsstaten som institutionelt udtryk for 'et system af totale ydelser'.

En generation senere fremhævede også den britiske sociolog Alvin Gouldner (19201980) reciprociteten som en grundlæggende (og universel) moralsk dimension (Gouldner 1973, kapitlerne 8 og 9), men understregede samtidigt dens begrænsninger. Der vil til ethvert tidspunkt være dem, der ikke er i stand til at gengælde ydelser, de måtte have modtaget. Fx vil personer med svær sygdom ikke kunne gengælde inden for en overskuelig fremtid. Børn kan være ude af stand til at yde gengæld inden for den periode, hvor giveren har behov for gengældelsens 'gave'. Mentalt handicappede kan ikke indgå i gensidigt forpligtende relationer.

Den, der (empatisk) kan leve sig ind i den fattige og den svages position, og den, som kan forestille sig selv at være svag og have hjælp behov, vil fornemme den skrøbelighed, der knytter sig til en fuldt gennemført forventning om reciprocitet. Den, der har set, hvordan mennesker til alle tider og på alle steder kan blive udsat for hårde tider, uheld, sygdom osv., og hvordan vi alle gradvis bliver gamle, trætte, helbredsplagede, uskønne, svage og funktionssvækkede, vil forstå, at også han eller hun kan få behov for andres støtte, selv om vedkommende vil være ude af stand til at yde gengæld.

Derfor er en gensidighedsnorm, hvor nødvendig den end måtte være for et socialt systems funktion, ikke en tilstrækkelig moralsk forudsætning til sikring af stabiliteten. Gouldner taler derfor $(1973,266)$ om en godgørenheds- eller kærlighedsnorm, som fordrer, at vi til andre giver den hjælp, de har behov, uden tanke på hvad de har gjort eller kan gøre til gengæld og uden hensyn til tidligere modtagne eller fremtidigt forventede modydelser, men udelukkende under hensyn til modtagerens behov. På kort form fordrer normen, at der ydes noget for ingenting.

Institutionelt finder ønsket om 'noget for ingenting' udtryk i en forpligtelse til at yde og ikke i en ret til at modtage. Det var det, der lå til grund for den oprindelige kirkelige 'gøren vel', som blev svækket i kølvandet på Reformationen. Det førte senere til en ny institutionalisering i form af fattigforordninger, som pålagde yderne en 'bidragspligt', der historisk gik forud for retten til at modtage, fordi man opfattede forpligtelsen til at give som svagere funderet end villigheden til at modtage. Det er først med den modne velfærdsstat, at den retlige dimension udvides fra skattepligten til også at omfatte retten til ydelser.

\section{Løgstrup som tolker af den danske velfærdsstat}

Det hævdes ofte, at velfærdsstatens moralske hovedhjørnesten er historien om den barmhjertige samaritan, der fremstiller det menneskelige grundvilkår, at livet er risikofyldt, og at vi er indbyrdes afhængige. Vi er hinandens verden og hinandens skæbne, selv om vi samtidig har en forestilling om, at vi ikke hører med til 'den andens' verden. 
Oplevelse af samhørighed og skæbnefællesskab står i et spændingsforhold til autonomi, individualisme og anonymitet; men historien brænder alligevel igennem, fordi den holder os fast på det, der måske i en dybere forstand er vores grundvilkår: forpligtelsen til at holde 'den andens liv' i vores hånd. Forpligtelsen på ansvaret er led i den kristne grundfortælling, der ser livet som gave med en forpligtelse til at leve livet som opgave. Bag det skænkede liv melder sig en skabermagt, som bliver instansen bag fordringen.

Derfor står teologen og filosoffen Knud E. Løgstrup (1905-81) som den, der måske mest markant har formuleret en etik, der kan læses som en tolkning af den danske velfærdsstat i dens dybdestruktur (Løgstrup 1956, 1972, 1976 og især 1996).

Han tager netop afsæt i samaritanerhistorien, som på et humant grundlag tolkes uden for forkyndelsens kategori i et forsøg på at sætte rammerne for en sekulariseret version af den kristne etik. ${ }^{3}$ Udgangspunktet er en ontologisk tradition, som lader ham tage afsæt i tilværelsens uforanderlige grundvilkår, der forvikler den enes liv med den andens. Det indebærer for ham den etiske fordring om at tage vare på det af den andens liv, som forviklingen prisgiver én (Løgstrup 1996, 20). Man kan kalde det en sekulariseret eller human udmøntning af kærlighedsbuddet, fordi han opfatter det som 'naturligt' i den forstand, at det simpelt springer ud af den anvisthed på hinanden, der hører tilværelsen til, men det er - forenklet og paradoksalt - også 'unaturligt', fordi det grundlæggende strider mod den menneskelige 'natur' ${ }^{4}$

Paradokset toner en spænding i henseende til, om det er individet eller fællesskabet, der har ontologisk primat. Spændingen følger, fordi væren ikke blot er eksistens, men samtidig væren som medlem af det samfund, man fødes ind i, jf. Skirbekk (1996, 34). Den enkelte er derfor altid en enkelt, der socialiseres inden for et fællesskab byggende på traditioner, betydningskoder, normer og opfattelser af personlig identitet. Sproget, viden, institutioner og social struktur er den arv, mennesket får i fødselsgave. Vi fødes ind i og optages som medlemmer af en væren med en nedarvet værensorden, der på

\footnotetext{
${ }^{3}$ Jeg skylder Ole Jensen den observation, at når den etiske fordring er en human udgave af Jesus' etiske forkyndelse, er det muligt, fordi den tilhører 'det universelle i kristendommen' i modsætning til den kristendomsspecifikke eskatologiske forkyndelse. Omvendt betyder fordringens humane karakter ikke, at den er 'gudløs' eller 'irreligiøs', fordi Løgstrup så tilværelsens ‘skabthed' som fænomenologisk påviselig. Om Løgstrups påstand er religiøs bliver derfor en ordstrid. Den er eksplicit religiøs, for så vidt den forudsætter et skænket liv, hvilket betinger fordringens ensidighed, men den er det ikke, for så vidt den i sig gennem fænomenets udtømmende beskrivelse indforstår en implicit, almen religiøsitet. Tilsvarende understreger Niekerk (2005), at Løgstrups 'humane' bestemmelse i sammenhængen betyder en 'almen' bestemmelse, dvs. en bestemmelse der er tilgængelig på almenmenneskelige vilkår uafhængigt af den kristne tro - en almen etik. Det er således en filosofisk bestemmelse, der på den anden side peger mod det specifikke i Jesus' forkyndelse, der ligger ud over, hvad man humant kan udsige om den menneskelige eksistens. Teologisk ligger Luthers lære om lex naturalis bag, dvs. ideen om en almenmenneskelig morallov givet i og med skabelsen, ligesom den Lutherske skelnen mellem lovens to funktioner klinger med. På den ene side lovens borgerlige brug som regulator af det menneskelige fælles liv og på den anden side lovens teologiske brug, der peger på syndserkendelsen som vejen til forkyndelsen af syndernes forladelse gennem Kristustro.

${ }^{4}$ I denne dobbelthed ligger netop Løgstrups paralleltænkning til lovens to brug, jf. Niekerk (2005). Den teologiske brug modsvares af fordringens radikale uopfyldelighed, mens den som grundlag for vore daglige gøremål har en 'praktisk' funktion.
} 
næste trin kan være mere eller mindre stabil, fordi den grundlæggende forudsætter en tillid til 'de andre'.

Det ontologiske argument sprænger selvsagt enhver form for utilitaristisk risikokalkule, når det drejer sig om den del af den sociale kontrakt, der har forsikringens funktion. Det normative argument hviler helt enkelt på ansvarligheden for 'den anden', uden hensyn til potentielle risici og gevinster.

En anden måde at tænke velfærdsstat på finder vi hos den amerikanske filosof John Rawls (1921-2002), der udfolder begrebet retfærdighed ved refleksion 'bag uvidenhedens slør' (Rawls 1972,1993). Når han lader forholdet til ‘den anden’ vige for idéen om retfærdighed, er hovedspørgsmålet, hvad 'den anden' har ret til, mens kærlighedsbuddet betinger, at medmennesket elskes for dets egen skyld. Man kan således tale om et livsverdensetisk fundament hos Løgstrup og et systemverdensetisk grundlag hos Rawls.

Mens retfærdigheden er forankret i loven eller idéen som det, der bestemmer forholdet til 'den anden' uden for den enkeltes konkrete virkelighed, er kærligheden knyttet til det umiddelbare møde ansigt til ansigt; men hvad har den da - knyttet som den er til de spontane og suveræne livsytringer - at skaffe med velfærdsstaten? Hvordan kan kærligheden antage en politisk dimension? Hvordan kan et etisk-eksistentielt valg lade sig transformere til et etisk-politisk valg?

Løgstrups argument er, at der kan knyttes en tråd, hvis man nedskriver etikken i dens radikale form til samfundsbrug, afradikaliserer og afemotionaliserer den. Hvis den barmhjertige samaritan - forarget over vejenes lovløshed - efter at være kommet til byen søger at rejse en folkestemning, der kræver 'mere politi på vejene', har han ændret karakter. Han er blevet politisk samaritan. I sit forsøg på at påvirke samfundsordenen, har han nedskrevet kærligheden til en idé, som ikke i sig selv indebærer kærlighedens fuldbyrdelse. Han kan måske endog glemme ham, der faldt i røvernes hænder, og lade sig fange ind af det problem, hvordan man sikrer den samfundsmæssige orden. ${ }^{5}$

Med kærligheden reduceret til idé, er der ingen, som fuldbyrder kærligheden. Der er ingen, der elsker næsten, men der er nogen, der tvinges til at bære sig ad, som om de gjorde det. At gøre brug af den gyldne regel som politisk idé er med samfundsindretningen at lade folk bære sig ad, som om de elskede næsten, vel vidende, at det gør de ikke, siger Løgstrup (1996, 56): "Normer lader sig ikke fuldbyrde, kun anvende. Spontane livsytringer lader sig ikke anvende, kun fuldbyrde" (Løgstrup 1996, 36). ${ }^{6}$

Selv om vi har en forforståelse af, hvad der er ret og rimeligt, rigtigt og forkert, skyer vi, når det drejer sig om at bjerge vor egen plads i solen, ingen midler. Vi kender fordringen, men vi er ikke voldsomt tilbøjelige til at følge den. Fristelsen er på spil,

\footnotetext{
${ }^{5}$ Som anført af Niekerk (2005) stammer Løgstrups sondring mellem næstekærligheden som fuldbyrdelse og som idé fra Løgstrup (1969) og udfoldes i Løgstrup (1971), der er optrykt i Løgstrup (1996).

${ }^{6}$ Med megen ret fremhæver Niekerk (2005), at normer ikke specificerer den etiske fordring, netop fordi den er tavs, men de har en vejledende betydning for fordringens konkretisering. Om end de er børn af tiden og derfor foranderlige, er de på afgørende vis bestemmende for opfattelsen af ret og vrang, godt og ondt i det samfund, de virker i. De både spejler og afspejler befolkningens tydnings- og forståelsesunivers.
} 
fordi det, moralen udspringer af, ikke længere har sindet i sin magt. Derfor søger vi pligten fastholdt gennem politiske beslutninger, der lægger et imperativ ned over os alle.

Ansvarligheden for at tage vare på den andens liv - vores indbyrdes ansvarlighed for hinanden - bliver i første instans kollektiviseret og i anden instans politiseret, fordi det er den eneste realistiske - eller i det mindste mest effektive - måde til at sikre dens varetagelse. Tages ansvarligheden for den andens liv overhovedet alvorligt, må refleksion over værens kontingente natur i sidste instans betinge, at det drejer sig om en kollektiv ansvarlighed, der må varetages kollektivt gennem politisk etablerede institutioner, jf. Goodin (1998, 155).

Samfundsordenens stabilitet, de nødvendige fælles spilleregler og den samfundsmæssige værensorden opfattes som et kollektivt gode, der i samme grad står til rådighed for alle - og som udspringer af menneskets almene fornuft og menneskelighed. Det giver på en og samme tid en begrundelse for udvikling af en velfærdsstat og en antydning af, at der i velfærdsstaten vil være spændinger mellem den individuelle praksis og samme velfærdsstats krav til den enkelte - dens værensorden.

Løgstrup argumenterer delvist parallelt til Gouldner, når han understreger, at uanset, at den anden intet har gjort for mig, skal jeg alligevel gøre det for ham, som han trænger til. Måske har den anden aldrig været i en position, så han har kunnet gøre noget for mig. Måske vil han aldrig komme i en sådan position, men da træder rolleombytningen ind, idet de velgerninger, som jeg, hvis jeg var i den andens sted, kunne ønske gjort mod mig, dem skal jeg gøre mod ham. Rolleombytningen modsvarer begrebet solidaritet $\mathrm{i}$ van Parijs forstand (1997, 387): Generøsitet mod andre i hvis situation, vi kunne have været, og som kunne forventes at handle på den måde, vi nu gør, hvis de havde været $\mathrm{i}$ vores situation og vi i deres. Gengæld er ingen hjulpet med, thi de, der trænger til hjælpen, er nok så ofte dem, der intet har kunnet yde til gengæld og måske heller aldrig vil kunne komme til det.

Det ontologiske perspektiv rejser spørgsmålet om, hvem man deler væren med. Den danske velfærdsstats oprindelse havde bl.a. nationalstatens etablering som baggrund. Man gik fra sogneforsørgelse til national forsørgelse, men nissen fulgte med. Den danske velfærdsstat er en konstruktion, der forudsætter, at folk lever hele deres liv i det land, hvor de fødes og har en indbyrdes, nationalt afgrænset solidaritet, så de, der klarer sig godt, finansierer velfærdsydelser til dem, der klarer sig mindre godt i forvisning om selv i givet fald at blive behandlet på samme måde. Det indebærer en dansk værensorden, der sættes under pres i en verden præget af mobilitet. Emigration indebærer risiko for, at nogle forlader landet og efterlader en regning (fx langvarigt uddannede) eller tager ophold i udlandet uden at betale dansk skat (pensionister). Immigration betyder, at nogle optræder som modtagere, uden at have haft status som bidragydere og med ringe udsigt til i fremtiden at blive det. Det gælder så meget mere, fordi velfærdsstaten bygger på en politisk kultur, der afspejler en 'overlappende enighed', som meget vel kan være tilflyttere med anden etnisk herkomst fremmed. Kort og brutalt er større mobilitet dårligt forenelig med en velfærdsstat (Skirbekk 1996, 43). Hvis der er markante forskelle i materiel standard landene imellem, er der en indlysende spænding 
mellem velfærdsstaten som ideal og idealet om menneskers frie bevægelighed. Umiddelbart disponerer et velfærdssystem for nødvendigheden af bevogtede politiske grænser, der beskytter mod mobilitet, men det rejser selvsagt grundlæggende etiske problemer. Hvor går solidaritetens grænser?

\section{Velfærdsstatens værensorden}

Systembaseret velfærd lægger restriktioner på den enkeltes praksis. Love og reguleringer skal overholdes, og 'systemet'/velfærdsstaten forudsætter et vist minimum af adfærdsmæssig solidaritet, der på det individuelle niveau ytrer sig i en moralsk forpligtelse og normative sanktioner. Velfærdsstaten forudsætter oplyste og moralske borgere, fordi ikke enhver form for egoistisk udfoldelse kan tolereres, jf. G. Skirbekk (1996). Den forudsætter også en fælles forståelse af, hvorfor og hvordan velfærden afhænger af alles bidrag. Uden en sådan fælles forståelse krakelerer 'systemet'.

De krav, velfærdsstaten stiller til den enkelte, er udmøntet i velkendte folkelige slagord som fx, at de bredeste skuldre skal bære de største byrder, at ingen unødigt skal ligge andre til last, og at vi skal gøre vores pligt og kræve vores ret.

Det er bare lettere sagt end gjort, fordi de institutioner, vi - velmenende - udvikler, påvirker normer og adfærd. Det kan skabe en spænding mellem praksis og prædiken.

Når 'systemet' har overtaget en ansvarlighed, der ellers skulle være min, føler jeg mig ikke længere konkret forpligtet i forholdet til 'den anden'. Når forpligtelsen bliver abstrakt og upersonlig, er det for den enkelte mere legitimt at smyge sig uden om, mens man omvendt har en tilskyndelse til at pukke på sin ret til de konkrete og personlige rettigheder.

Velfærdsstatens sprog bliver derfor rettighedernes sprog, mens forpligtelserne nedtones. I stedet for vore indbyrdes forpligtelser oplever vi at have krav på hinanden. Når forpligtelsen politisk er nedskrevet i forhold til kærlighedsbuddet, oplever vi, at fordringen kan indfries uden vores selvstændige medvirken. 'Dette er et problem, nogen - læs samfundet - må tage sig af', siger vi.

Pointen er i svensk sammenhæng behandlet af sociologen Hans Zetterberg (1984). Mens humaniteten fordeles ligeligt efter den rationelle velfærdsstats logik, mister den sit hjerte. Det fremkalder det etiske perspektivs paradoks, nemlig at den formaliserede humanitet sameksisterer med den spontane humanitets fravær. Sagt med den danske historiker Henrik Jensens (2004) ord afmelder den velbjergede borger sine forpligtelser, mens han dirigerer 'værdigt trængende i sin egen familie videre mod de statslige institutioner'.

Bag disse udsagn ligger en tanke om borgeren som rationel aktør, der i samspillet med velfærdssystemet maksimerer sin nytte - spændingen mellem en hedonistisk adfærd og en ontologisk etik. Det har også tidligere professor i socialpolitik og socialminister Bent Rold Andersen (1983, 1984a, 1984b) været inde på, da han understregede, at velfærdsstaten er sårbar, fordi den universelle dækning, fleksibiliteten og den indre rationalitet har fjernet det, der kunne erindre om, at ydelserne ikke flyder fra en uudtømmelig brønd, men at de betales af os selv som skatteydere. Derfor har den 
skabt et 'gratistproblem', dvs. en adfærd hos en rationel person i et system, hvor faktorer, der økonomisk hører sammen, og som derfor samlet burde indgå i den enkeltes overvejelse, systematisk behandles isoleret. Paradokset i den danske velfærdsstat er, at borgerne, hvis den skal fungere i overensstemmelse med dens mål og dens værdier, skal undlade at udnytte dens tilbud i deres fulde udstrækning. Motiveret i en uformel social kontrol, der svækkes ved velfærdsstatens vækst, skal borgerne opføre sig privatøkonomisk irrationelt; men det er kun få borgere, der på denne måde agerer loyalt og offervilligt over for 'systemet'. Den rationelle konklusion er ikke at vise solidaritet ved at undlade at 'presse systemet', men modsat at gøre som, man tror, de andre gør. Når reglerne er ens for alle, og når alle udnytter dem i lige høj grad, er der ingen, der bliver snydt.

Allerede i 1960 pegede forfatteren og debattøren Peter P. Rohde (1902-1978) på kapløbet mellem de politiske partier, der indebar køb af vælgerbefolkningens gunst ved at love større og større sociale ydelser (Rohde 1960). Det kunne, sagde han, korrumpere velfærdsstatens idé og forvandle den til en form for bestikkelse. En sådan overbudspolitik kunne forvandle det nydende flertal til passive modtagere, som ikke følte en forpligtelse til at yde men betragtede det som en selvfølge, at alt blev givet, jf. også Buchanan (1991).

Hvor fornem etikken bag den danske velfærdsmodel som idealtype end er, er modellen spændingsfyldt. Hvis sindelaget mangler, sagde Løgstrup, må gerningerne fremtvinges; men vi har ikke let ved at glemme vore selviske tilskyndelser, og det skaber et skisma mellem velfærdsstatens fundamentale krav til vores gøren og laden velfærdsstatens værensorden - og den samtidige impuls til at presse 'systemet'.

Der er ikke meget i den velfærdsstatslige dagligdag, der stimulerer til den fornødne besinden sig. Selvbegrænsning og selvansvarlighed med direkte adresse til den enkelte. Når vi aktuelt oplever at være i betalerens rolle eller på anden måde at skulle indfri forpligtelsen over for andre, da en besinden sig på den fornødne generøsitet i forhold til de ringere stillede. Når vi aktuelt oplever at være i en situation, der potentielt kan udløse en ydelse, da en besinden sig på en vis tilbageholdenhed for ikke at 'overanstrenge' systemet. 'Systemet' er jo nemlig vores nabo og næste, ja, 'de andre' er os selv; men det skjuler netop de regler, der skulle knæsætte moralen. De skulle til, fordi fristelsen var på spil; men regler eller ej, fristeren er altid på spil.

Socialpolitikkens etiske grundlag er en vurdering af dens 'regler' fra et moralsk synspunkt, en undladelse af at 'udnytte' smuthuller i loven og en adfærd, der hviler på moralske beslutninger styret af den enkeltes samvittighed, siger Koslowski $(1997,347){ }^{7}$ Hver for sig må vi handle, så velfærdsstaten, hvis alle andre opfører sig på samme måde, kan overleve; men både de formelle regler og den manglende forståelse sætter grundforudsætningen på spil. Der er en indlysende risiko for en afvigelse mellem

\footnotetext{
${ }^{7}$ Når næstekærligheden er nedskrevet til politisk idé, er det ikke alene de gældende sociale normer, der ligger til grund for politiske overvejelser. $\mathrm{Nu}$ optræder den etiske fordring som positiv norm med kritisk potentiale for indretning af samfundet.
} 
forståelsen af velfærdsstaten som et nomos og en mere dagligdags tolkning, når man konkret forholder sig til den.

\section{En modgående bevægelse}

Artiklen har betonet den fælles ansvarlighed, der i endelig forstand betinger maksimen om noget for ingenting, som kerne i den danske velfærdsstats normative grundlag. Det er også understreget, at den forudsætter en samfundsmæssig værensorden, som kan være i modstrid med de individuelle tilskyndelser. Og det er fremhævet, at der kan være et spændingsforhold mellem de foranstaltninger, vi kollektivt har frembragt for at modarbejde 'fristelsen', og fristelsen i sig selv - eller mellem den 'solidaritet', som systemet forudsætter og en atomiseret individualisme. ${ }^{8}$

Det bør derfor, inden vi ser på forholdet mellem objektiv og subjektiv virkelighedsforståelse, nævnes, at der over de senere år er gennemført nydannelser, som markerer en vis bevægelse i den danske velfærdsstat væk fra dens knæsatte grundprincip. Flere af dem kan der absolut anføres gode grunde for, men de spejler et andet paradigme, end det der har været fremherskende i en lang historisk udvikling.

Det begyndte i 1964 med Arbejdsmarkedets Tillægspension, der ikke er skattefinansieret, som kun dækker dele af befolkningen, og som har en noget uklar fordelingsprofil. I 1989 indførte man arbejdsmarkedspensionerne, der er bygget på markedets aktuariske mekanisme. Ved efterlønsforliget i 1999/2000 blev indbetalingerne individualiseret, så den enkelte kan overføre dem til vedkommendes egen pensionsordning. Den særlige pension, der blev gennemført 1997/98, har - bortset en kortere periode - været et rent individualiseret arrangement. Flere og flere tegner sundhedsforsikringer uden for det offentlige system, og faglige organisationer for højere lønnede opbygger supplerende arbejdsløshedsdagpengeforsikringer. Aktivering og andre foranstaltninger anvendes $\mathrm{i}$ stigende grad som en modydelse for den offentlige kontante understøttelse.

Vi skal ikke her fortabe os i begrundelserne for disse ændringer, men kun stilfærdigt påpege, at den danske velfærdsstat er under en upåagtet ændring, der måske vil svække dens hævdvundne grundprincip.

Man kunne mene, at velfærdsstaten i stigende grad ses som et til markedet analogt leveringssystem, der skal tilfredsstille individuelle behov, jf. flere bidrag hos Eriksen \& Loftager (1996). Den enkelte ses som forbruger snarere end som borger. Også det er en udfordring til velfærdsstatens nomos.

\footnotetext{
${ }^{8}$ Modstillingen mellem 'fristelsen' og modernitetens tab af forståelsen af modtagelse/ensidighed formulerede Løgstrup ikke. Den rejser, har Ole Jensen gjort opmærksom på -ikke mindst i sammenhæng med min senere inddragelse af Peter Bergers refleksioner - spørgsmålet, om den svækkede sans for solidariteten/ensidigheden kalder på en revitalisering af det alment religiøse, jf. note 3 eller af syndserkendelsen: Den livsoplysende skole eller kirken eller begge?
} 


\section{Den hellige baldakin}

Reformationens arv var tvetydig. På den ene side lagde den middelalderkirkens religiøse hierarki bag sig og betonede det almene præstedømme med troen som eneste tråd til Gud, mens den protestantiske samfundsdoktrin på den anden side fastholdt et hierarkisk samfund og en social orden, der blev afledt af Guds autoritet (Thorkildsen 1997, 144). Det indebar en sær dobbelthed. Kirken var statens værktøj med sognepræsterne som både Guds og kongens øje og stemme selv i de mest afsides samfund (Knudsen 2000b); men samtidig spillede kirken og dens idéer en aktiv rolle. I første omgang var stat og kirke fælles om det kirkelige projekt, der sigtede på et samfund, hvis menneskeliv var i overensstemmelse med kristne normer, og hvis værdigrundlag havde kristne grundholdninger som kerne (Ingesman 2000). Først i det 18. århundrede begynder staten at forfølge egne mål delvis i forlængelse af og delvis i modsætning til kirkens. Borgerne skulle på en og samme tid opdrages til at være gode kristne og nyttige samfundsborgere. Pietismen og oplysningen satte dette dobbeltleddede projekt under pres ved betoningen af religionen som en privat sag og staten som en ikke religiøs størrelse. Det betød en stærkere vægtlægning på værdier som borgerdyd, fædrelandskærlighed, ansvarlighed, troskab mod kongen osv. Det 'gode samfund' erstattede det kristne samfund som overordnet værdi, hvilket gradvis opløste præstens nøglerolle, fordi samfundsordningen ikke længere skulle motiveres religiøst og ikke længere indplaceres i et religiøst verdensbillede (Gustafsson 2000).

Denne udvikling blev forstærket ved det 19. århundredes vækkelsesbevægelser og deres samspil med eller i det mindste deres indvarsling af den politiske liberalisme, der pegede mod den sekularisering, som for de fleste ytrede sig i religiøs og ideologisk individualisering, differentiering og pluralisme i modsætning til det før-moderne samfunds religiøse enhed.

Den gradvise integration af vækkelsen i den officielle kirke og statskirkens omdannelse til folkekirke - eller national kirke - var led i en moderniseringsproces, som i svøb peger frem mod den moderne velfærdsstat, der i nogen grad har den lutherske protestantisme som forudsætning. Vækkelsen betonede den moralske adfærd, opfattede det daglige arbejde som en tjeneste for Gud og livet efter 'omvendelsen' som et sobert og simpelt liv (Thorkildsen 1997, 147). Sammen med opfattelsen af arbejdet som et kald disponerede det for en aktiv og produktiv etos med vægt på selvdisciplin og selvbegrænsning. Det peger frem mod velfærdsstatens betoning af fuld beskæftigelse som mål. Dens lighedsdimension har rødder i tanken om det almene præstedømme og ligheden for Gud. Dens betoning af samfundet som 'en stor familie' - folkhemmat med gensidigt ansvar har rødder i lutherdommens betoning af husholdningen og ægteskabet. Betoningen af 'folket' - forstået som alle sociale klasser - nedtonede klassestridigheder til fordel for national velfærd (Stråth 2005, 35). Protestantismens opgør med 'gerningsretfærdigheden' og dens understregning af Guds ensidige nådeshandling kan måske ses som et opgør med reciprociteten i gudsforholdet. Den positive holdning til statsmagten som instrument for velfærdens fremme er næppe uden sammenhæng til den statskirke, som på en og samme tid forvaltede nåden og kongens 
bud, og til den periode, hvor kirkens og statens love og normer i vid udstrækning var sammenfaldende. Levine (1973) noterer i sin analyse af den tidlige danske socialpolitik, at begreberne 'samfund', 'det offentlige', 'stat og kommune' blev anvendt som noget nær synonymer, jf. også Stråths (2005, 36ff) analyse af Tönnies' begreber 'Gemeinschaft' og 'Gesellschaft' $\mathrm{i}$ en svensk kontekst. Man så ikke 'samfundet' som en modsætning til 'staten' eller som en sfære mellem 'stat og marked'. Helt svarende til Levines observation om Danmark, fremhæver Stråth, at det semantiske felt om begreberne 'stat, samfund og fællesskab' var overlappende og ikke brudpræget.

Selv om det således kan sandsynliggøres, at velfærdsstaten som moderne projekt har rødder i kirken som institution og måske i kirkens forkyndelse, og selv om kristendommen kan ses som en af sekulariseringens baggrundsfaktorer, er den nutidige situation præget af 'den fjerne kirke' og en pluralisme, der lader forkyndelsen være en blandt flere stemmer. Det kan være forklaringen på den spænding, Løgstrup antyder, når han lader kærlighedsbuddet være 'naturligt', fordi det følger af den anvisthed på hinanden, der hører tilværelsen til, men samtidigt - forenklende - lader det være 'unaturligt' i den forstand, at det grundlæggende strider mod den menneskelige 'natur' menneskets 'indkrogethed' i sig selv, som Luther sagde. Den objektive fakticitet står i et spændingsforhold til den subjektive perception - måske som konsekvens af religionens tilbagetrukne rolle under modernitetens vilkår?

Indirekte afledt af Durkheims (1858-1917) anomibegreb (Durkheim 1970) taler sociologen Peter Berger (1967) om nomos som en meningsfuld orden, der er påtvunget individernes erfaringer og tolkninger gennem den socialt konstruerede verden (Berger 1967, 19). At tage del i samfundet er ensbetydende med at dele samfundets 'viden', dvs. at være 'samboende' (med andre) i dets nomos (Berger 1967, 21).

Hvis det samfundsmæssigt etablerede nomos tages for givet, vil dets betydningsimplikationer smelte sammen med universets iboende mening. Betydningerne i den menneskeligt konstruerede orden projiceres over i universets orden, hvilket lader nomos' stabilitet hvile på mere magtfulde kilder end menneskers historiske indsats (Berger 1967, 24-25). Heraf følger et samspil mellem nomos og kosmos, der antyder religionens betydning, uden at kosmos nødvendigvis spejler 'det hellige'.

Alle menneskeligt konstruerede verdener har en iboende usikkerhed og er konstant truet af menneskelig selvinteresse og dumhed. Truslen søges imødegået gennem socialisering og legitimering med sigte på udvikling af en symmetrisk relation mellem de objektive og subjektive virkelighedsdefinitioner (Berger 1967, 32).

Grundlæggende vil en fremtidig fastholdelse af en institutionel orden - bortset fra anvendelse af magt - bedst sikres, siger Berger, ved at lade den fremstå så lidet 'konstrueret' som muligt, fordi så mange som muligt da ser den som deres egen tilværelses dybeste aspirationer (Berger 1967, 33). Netop en religiøs dimension - i den ene eller den anden form - tillægger i endelig forstand de sociale institutioner en ontologisk status, fordi den indplacerer dem i en kosmisk referenceramme. Deres empiriske skrøbelighed ændres til en stabilitet, når de ses som manifestationer af en underliggende dybdestruktur, der for den enkelte såvel kognitivt som normativt 
definerer den rolle, han eller hun skal spille i samfundet (Berger 1967, 37), og når tydningsuniverset holdes intakt gennem ritualisering $i$ den ene eller den anden form.

Verdener er sociale konstruktioner, der kræver social opretholdelse. Deres objektive og subjektive virkelighed afhænger af sociale processer, som løbende rekonstruerer og fastholder dem. Som grundlag for sin fortsatte eksistens forudsætter enhver verden, at den fremtræder som virkelig for de mennesker, der bebor den. Den må med Bergers formulering have en 'plausibilitetsstruktur' (Berger 1967, 45).

Hvis en værensorden skal opfattes som legitim, må den kunne retfærdiggøre sig i den subjektive værensforståelse. Det forudsætter et symbolsystem, der tjener til udvikling af stærke, gennemtrængende og varende menneskelige stemninger og motivationer indlejret i forestillinger om en generel værensorden iklædt en sådan aura af fakticitet, at stemninger og motivationer forekommer den enkelte at være konsistent med hans eller hendes begreb om den etablerede verdens nøgne kendsgerninger. Pudsigt nok er det Clifford Geertz' $(1973,90)$ definition på en religion. Hvis nomos og kosmos ikke (længere) falder sammen, fordi grundfortællingen er gået tabt, kan velfærdsstaten for sin beståen alene henvise til sig selv. Deraf følger måske aporien.

\section{Litteratur}

ANDERSEN, BENT R.

1983 Two Essays on the Nordic Welfare State, AKF Forlaget, København.

1984a "Rationality and Irrationality of the Nordic Welfare State", Doedalus, 111-39.

1984b Kan vi bevare velfcerdsstaten, AKF Forlaget, København.

Berger, Peter L.

1967 The Sacred Canopy, Anchor Books, Doubleday, New York, London, Toronto, Sydney, Auckland.

BEVERIDGE, WiLLIAM

1942 Social Insurance and Allied Services, HMSO, CMND 6404, London.

BUCHANAN, JAMES M.

1991 "Potential and Limits of Socially Organized Humankind", in: J.M. Buchanan, The Economics and Ethics of Constitutional Order, The University of Michigan Press, Ann Arbor, 239-52.

DiCH, JøRGEN

1952 “Ideer og Interesser i Praktisk Politik", Socialt Tidsskrift 28, 43-53.

1958 "Den moderne velfærdsstats økonomiske problemer”, Nationaløkonomisk Tidsskrift 96, $17-50$.

1965 "Udviklingen af skatte- og tilskudspolitikken siden 1939. Et bidrag til forklaring af de politiske kræfter i Danmark siden 1939”, Økonomi og Politik 39, 225-60.

1973 Den herskende klasse. En kritisk analyse af social udbytning og midlerne imod den, Borgens Forlag, København.

DURKHEIM, EMILE

1970 Suicide, A Study in Sociology, Routledge, London. (Først udgivet i 1897).

ERIKSEN, ERIK O. \& J. LOFTAGER

1996 The Rationality of the Welfare State, Scandinavian University Press, Oslo.

1996a "Challenging the Normative Foundation of the Welfare State", in: The Rationality of the Welfare State, Scandinavian University Press, Oslo, 1-11. 
GEERTZ, CLIFFORD

1973 "Religion As a Cultural System", in: Clifford Geertz, The Interpretation of Cultures, Fontana Press, London, 87-125.

GOODIn, ROBERT E.

1988 Reasons for Welfare, The Political Theory of the Welfare State, Princeton University Press, Princeton, New Jersey.

1998 "Social Welfare as a Collective Social Responsibility", in: David Schmidtz \& Robert E. Goodin, Social Welfare and Individual Responsibility, For and Against, Cambridge University Press, 97-195.

GOULDNER, ALVIN

1973 For Sociology, Allen Lane, London.

GuSTAFSSON, HARALD

2000 "Præsten som velfærdsforvalter i tidligt moderne tid", in: Tim Knudsen, ed., Den nordiske protestantisme og velfcerdsstaten, Aarhus Universitetsforlag, Århus, 87-97.

INGESMAN, PER

2000 "Kirke, stat og samfund i historisk perspektiv", in: Tim Knudsen, ed., Den nordiske protestantisme og velfcerdsstaten, Aarhus Universitetsforlag, Århus, 65-86.

JENSEN, HENRIK

2004 "Min broders vogter? Om troen på velfærdsstaten", in: Jørn Henrik Petersen \& Klaus Petersen, eds., 13 udfordringer til den danske velfcerdsstat, Syddansk Universitetsforlag, Odense, 29-46.

KASPERSEN, LARS BO

2005 "The origin, development, consolidation and transformation of the Danish welfare state", in: Nanna Kildal \& Stein Kuhnle, eds., Normative Foundations of the Welfare State. The Nordic Experience, Routledge, London, 52-72.

KILDAL, NANNA \& STEIN KUHNLE

2005 Normative Foundations of the Welfare State. The Nordic Experience, Routledge, London.

2005a "The Nordic welfare model and the idea of universalism", in: Nanna Kildal \& Stein Kuhnle (2005), Normative Foundations of the Welfare State. The Nordic Experience, Routledge, London, 13-33.

KNUDSEN, TIM

2000a "Indledning", in: Tim Knudsen, ed., Den nordiske protestantisme og velfcerdsstaten, Aarhus Universitetsforlag, Århus, 7-19.

2000b "Tilblivelsen af den universalistiske velfærdsstat", in: Tim Knudsen, ed., Den nordiske protestantisme og velfcerdsstaten, Aarhus Universitetsforlag, Århus, 20-64.

KOSLOWSKI, PETER

1997 "The Social State in the Post-Modern", in: Peter Koslowski \& Andreas Føllesdal, eds., Restructuring the Welfare State, Theory and Reform of Social Policy, Springer, Berlin, 337-79.

LEVINE, DANIEL

1973 "Den ideologiske baggrund for dansk sociallovgivning, 1890-1933", in: Scandia 39, 20114.

LINDBERG, NIELS

1951 Idealer og regler $i$ anvendt økonomik, Nyt Nordisk Forlag, København.

LøGSTRUP, KNUD. E.

1956 Den etiske fordring, Gyldendal, København. 
1969 "Politik og etik", in: Politica, Tidsskrift for politisk videnskab 2, 12-26.

1971 "Etiske begreber og problemer", in: Gustaf Wingren, ed., Etik og kristen tro, Gyldendal, København, 205-86. Senere genoptrykt som Løgstrup (1996).

1972 Norm og Spontaneitet, Etik og politik mellem teknokrati og dilettantokrati, Gyldendal, København.

1976 Skabelse og Tilintetgørelse. Religionsfilosofiske betragtninger. Metafysik IV, Gyldendal, København.

1996 Etiske begreber og problemer, Gyldendal, København.

MACINTYRE, ALASDAIR

1999 Dependent Rational Animals, Duckworth, London.

MAUSS, MARCEL

2000 Gaven. Gaveudvekslingens form og logik $i$ arkaiske samfund, oversat til dansk med forord af Anne Knudsen, Spektrum, København (først udkommet som "Essai sur le don. Forme et raison de l'échange dans les sociétés archaïques", l'Année Sociologique, seconde série, 1923-24).

NiEKERK, KeES VAN KoOTEN

2005 “K.E. Løgstrups politiske tænkning”, upubliceret manuskript.

OfFe, Claus

1990 “Akzeptans und Legitimität strategischer Optionen in der Sozialpolitik", in: Christoph Sachße \& H. Tristam Engelhardt, eds., Sicherheit und Freiheit, Zur Ethik des Wohlfahrtsstaates, Suhrkamp Verlag, Frankfurt am Main, 179-202.

PARIJS, PHILIPPE VAN

1997 "On the Moral Foundations of the Welfare State", in: Peter Koslowski \& Andreas Føllesdal, eds., Restructuring the Welfare State, Theory and Reform of Social Policy, Springer, Berlin, 382-92.

Petersen, JøRn HenRIK

1986 "Three Precursors of Modern Theories of Old Age Pensions. A Contribution to the History of Social Policy Doctrines", History of Political Economics 18, 405-17.

2005a "Reforms of European Retirement Schemes, The Danish Case" (upubliceret manuskript).

2006 Den danske alderdomsforsørgelseslovgivnings udvikling II, 1891-1933, under udgivelse.

RAWLS, JOHN

1972 A Theory of Justice, Oxford University Press, Oxford.

1993 Political Liberalism, Columbia University Press, New York.

RoHDE, PeTER P.

1960 "Velfærdsstat og åndsliv", Perspektiv 8, 2, 5-12.

ROTHSTEIN, BO

1996 "The Moral Logic of the Universal Welfare State", in: Erik O. Eriksen \& J. Loftager, (1996), The Rationality of the Welfare State, Scandinavian University Press, Oslo, 98119.

SAmuelson, Paul A.

1958 "An exact consumption-loan model of interest with or without the social contrivance of money”, Journal of Political Economy 66, 467-82.

SCHREIBER, WINFRIED

1955 Existenssicherheit in der industriellen Gesellschaft, Vorschläge des Bundes katholischer Unternehmer zur Reform der Sozialversicherungen, Schriftenreihe des Bundes katholischer Unternehmer, N.F., Köln. 
SIMMEL, GEORG

1907 Philosophie des Geldes, Duncker \& Humblot, Leipzig.

1908 Soziologie. Untersuchungen über die Formen der Vergesellschaftlichung, Duncker \& Humblot, München og Leipzig.

SKIRBEKK, GUNNAR

1996 "The Idea of a Welfare State in a Future Scenario of Great Scarcity", in: Erik O. Eriksen \& J. Loftager, (1996), The Rationality of the Welfare State, Scandinavian University Press, Oslo, 28-54.

STENIUS, HENRIK

1997 "The Good Life Is a Life in Conformity: The Impact of the Lutheran Tradition on Nordic Political Culture", in: Øystein Sørensen \& Bo Stråth, The Cultural Construction of Norden, Scandinavian University Press, Oslo, 161-71.

STRÅTH, BO

2005 "The normative foundations of the Scandinavian welfare states in historical perspective", in: Nanna Kildal \& Stein Kuhnle, (2005), Normative Foundations of the Welfare State. The Nordic Experience, Routledge, London, 34-51.

THORKILDSEN, DAG

1997 "Religious Identity and Nordic Identity", in: Øystein Sørensen \& Bo Stråth, The Cultural Construction of Norden, Scandinavian University Press, Oslo, 138-60.

WESTERGAARD, HARALD

1926 "Spørgsmålet om aldersrente", Nationaløkonomisk Tidsskrift 64, 233-39.

ZETTERBERG, HANS L.

1984 “The Rational Humanitarians”, Doedalus, 75-92.

Jørn Henrik Petersen

Professor, dr.phil. \& lic.oecon.

Center for Velfærdsstatsforskning

Institut for Statskundskab

Syddansk Universitet 